\title{
THE INFLUENCE OF GEOMETRIC CHARACTERISTICS OF THE PRODUCT ON THE MOISTURE LOSS KINETICS
}

\author{
I.V. Dovgan, Doctor of Chemical Sciences, Professor, ORCID: 0000-0002-6195-4890 \\ A.V. Kolesnikov, PhD., Assistant Professor, ORCID: 0000-0001-8737-0933 \\ S.V. Semenova, PhD., Assistant Professor, \\ svetas@inbox.ru, ORCID: 0000-0002-5309-5854 \\ G.A. Kyrylenko, ORCID: 0000-0001-9377-1530 \\ E.A. Makovetskaya, ORCID: 0000-0002-3135-4333 \\ Odessa State Academy of Civil Engineering and Architecture
}

\begin{abstract}
The article is devoted to the influence of the geometric characteristics of the building products surface on the processes of moisture loss during their drying. Drying of a building product is considered as an active physical and chemical process and sensitive to the geometric properties of the moisture transfer flows. The characteristic of these flows is determined, especially, by the boundary conditions, imposed on the humid composite by the sample shape or structure. Due to the fact that the drying of any building product is a complex process, determined by the interrelated changes of the local moisture content, the deformation of the composite and changes at its physical and chemical characteristics, the total effect of the boundary conditions of the moisture sample loss rate of the samples was experimentally investigated. The rate of mass loss due to drying under standard conditions of a series of cubic samples, partly covered with a polymer film is considered in such a way that the areas of the face sections and parts of the surface, containing the edges and vertices free for moisture evaporation remain identical. The moisture loss kinetics was studied using the construction and analysis of the normalized moisture content graph and the corresponding differential graphical dependencies. On the basis of the differential graphs, the intervals of constant speed of moisture loss and reduction of the drying rate were distinguished. It is shown that the interval of constant drying rate in the case of a sample with the isolated edges and vertices is significantly longer compared with a sample with the isolated faces. The speed reduction interval of the drying rate is the smallest in the case of a control sample and the largest in the case of a sample with the isolated edges and vertices. The conceptual interpretation of the obtained results is given: the moisture loss rate both in the case of the constant drying rate mode and in the fall of the drying rate is higher for the samples with the free edges and angles than for the samples with the free faces due to the geometry influence of the sample surface (its curvature) on the evaporation processes and moisture movement through the capillary network of the material. Thus, the significant effect of the geometry surface of the samples, its curvature, the presence of the edges and angles, the nature of moisture loss are demonstrated. The possibility of creating building products with special geometry (the presence of edges and curvature) is considered to optimize the drying processes and minimize the effects of moisture destruction of the material.
\end{abstract}

Keywords: moisture loss rate, moisture transfer, drying, surface geometry.

Introduction The most important task of building materials technology is optimizing the functioning of the building composite at each stage of its life cycle. The implementation stage of the material operating ability in the structures is inevitably connected with the processes of humidifying and drying that occur cyclically. Operating ability of the composite in the process «humidifying - drying»; the internal stress, strain and ultimate strengths are exposed to change comprising the periodic component and a trend.

Therefore, it is important to study the mechanisms of moisture processes in materials and the influence of the shape of products or structures on these processes.

Inside the composite materials and products, having a complex structure, the moisture transfer 
occurs due to the various mechanisms that act very often at the same time. The moisture transfer, physical and chemical changes in the material and internal deformation are a single process, the physical changes of which are not divided and considered separate. So, the drying process of the material consists of moisture moving inside the material, vaporizing and moisture moving from the material surface to the environment. When a wet material comes in contact with air, the liquid on the surface evaporates and as a result of diffusion leaves the material surface of the, passing into the environment [1]. The evaporation of moisture from the material surface creates the difference in moisture content between the next layers and the surface layer, which causes diffusion-induced movement of moisture from the underlying layers to the surface ones. During the drying process, there is a continuous supply of moisture from the inner ones to the surface layers of the material; as a result the moisture decreases not only on the surface, but also in the depth of the material [2]. In the simplest case, the evaporation occurs on the surface of the material, and the resulting vapor diffuses into the environment.

Management and optimization of the above processes can be carried out from different positions. The increase of moisture resistance and the effect on the vapor permeability of the material by changing its composition, as well as internal and surface hydrophobization, are traditional. Another way to influence the processes of moistening and drying is changing the curvature of the sample surface, creating ribbed and shaped surfaces in order to intensify the processes of moisture evaporation. Thus, it is possible to optimize the shape of the structure to speed up the drying processes and the final reduction of the negative effect of humidity on the strength and structural characteristics of the material.

Analysis of the latest research. The regularities of the development of moisture deformations are determined by the balance of forces of water coupling with the solid phase and the pore space, which can develop in the structure of the material when its moisture content changes [3, 4].

The materials moistened and dried in the solid state, have been studied quite well. For such materials, you can use some models [3]. In the case of wetting with pure water, the materials during their drying, have the properties similar to homogeneous porous bodies. Porous media [4, 5] can serve as a pattern model for assessing similarities and differences with real materials. During the drying process, simple materials show the first constant speed mode, during which the drying speed is approximately constant. This period lasts up to the level of moisture loss $10-20 \%$. During this period, the saturation is uniform and the evaporation occurs from the outer liquid surface of the film close to the free surface of the sample. In this case, the fluid is drained due to the capillary effect through the film network throughout the sample. Then the drying rate decreases, the under speed condition is observed. In this mode, the fluid flow, due to the capillary effect, cannot provide fluid delivery at the sufficient rate to the free surface of the sample, a dry area is formed. It reduces the drying rate due to the functioning of this region as a diffusion barrier for steam. The size of the dry area increases as the sample dries. Finally, the last mode occurs when the dry area increases to such an extent that the moisture flow does not reach the external borders of the sample. Such a mechanism of drying processes is confirmed with the NMR method [6]. Moisture transfer affects the transportation and crystallization of salts, which can lead to the formation of structures in gypsum stone and other porous media, such as glass beads and burnt clay [7-10].

It is necessary to note that moisture transfer and moisture loss during drying should be considered in close interrelation between mechanochemical phenomena in the material. When the material is dried, by means of the influence of capillary forces, the significant strain gradients are created and new interfaces and technological cracks are formed. Some of these elements play an active role in the processes of strength reducing and material destruction [11, 12].

In our opinion, the processes, associated with moisture loss during drying, taking into account the specific boundary conditions caused by sample geometry, were studied both experimentally and theoretically, insufficiently. 
Targets and goals. The aim of the work is to study the influence of the geometric shape of building products on the drying processes under standard conditions. The tasks are the study of moisture loss of model gypsum samples under boundary conditions that limit moisture evaporation from the sample and provide moisture transfer through the surfaces with different geometric characteristics.

Objects and research techniques. The object of the investigation is a molded composite material based on gypsum in the process of moisture loss (at $\mathrm{t}=20^{\circ} \mathrm{C}, \mathrm{P}=101.3 \mathrm{kPa}, \mathrm{W}=40 \%$ ) under various conditions on its surface.

Studying the direction of moisture transfer processes in hardened binding materials, the gypsum binder (gypsum G-5-B-II (DSTU B B. 2.7-82: 2010) produced by "Ivano-Frankivsk Cement") was used. Samples were molded without compaction in triple metal molds with a size of $100 \times 100 \times 100 \mathrm{~mm}$.

The water content was selected before providing a stable spread diameter according to Suttard $-18.5 \mathrm{~cm}$. Gypsum binder paste was prepared normally and poured into forms in the room with an air temperature of $20 \pm 2{ }^{\circ} \mathrm{C}$. The samples were taken and weighed. Then the samples were saturated with water.

Then, the samples were processed as follows:

a) in the first sample 1 the angles of all faces were sealed with a polymer film (Fig.1, a);

b) in the second sample 2, the ends of the faces were sealed with a polymer film (Fig.1, b).

The surface of the third sample was not processed, it was a control one for weight analysis of moisture content.

In samples 1 and 2, the areas of the sealed surfaces are equal. With this processing method of the samples faces, moisture transfer will be carried out along different directions: for sample 1 through the surfaces of the faces, for sample 2 - through the rib and angular surfaces.

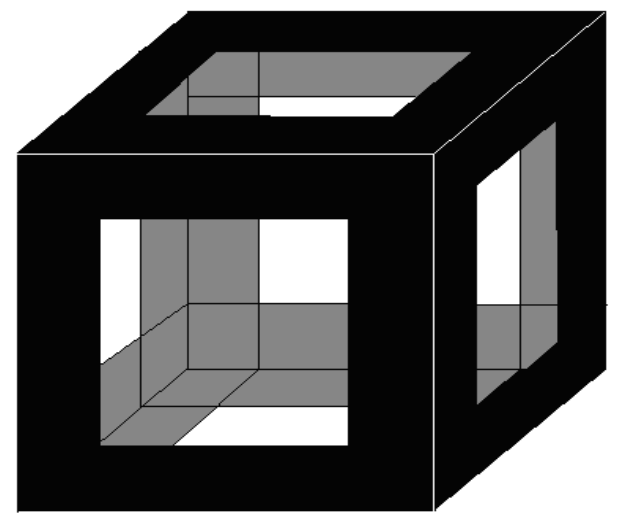

a)

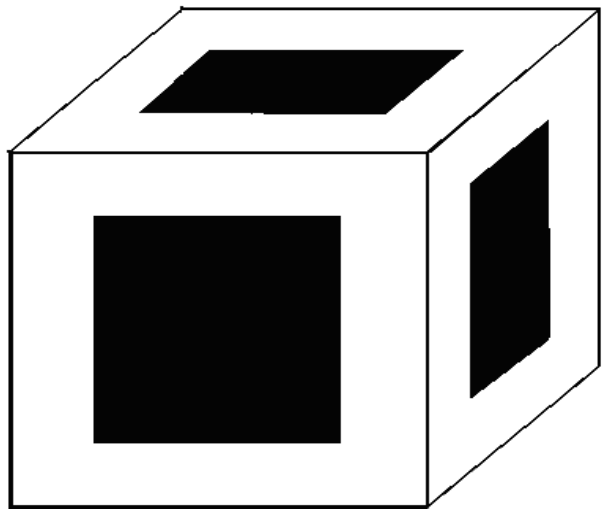

b)

Fig. 1. Diagram of moistened gypsum samples with a partially isolated surface (sealed with polymer film): $a$ - angular and rib parts of the surface; $b$ - the central parts of each face

Then the samples were weighed during the process of drying to the equilibrium moisture under standard conditions (at the temperature $20^{\circ} \mathrm{C}$ and a relative humidity $40 \%$ ). The samples were weighed once a day during 14 days until the complete mass change of the samples.

The results of the research. The results of weighing of three samples are presented in Table 1 . According to Table 1 the samples have lost $~ 20 \%$ of the mass by the end of the test period due to drying, then their mass is stabilized. 
Table 1 - Samples' masses during the drying period

\begin{tabular}{|c|c|c|c|c|c|c|c|c|c|c|c|c|c|c|}
\hline \multirow{2}{*}{ No } & \multicolumn{2}{|c|}{1 day } & \multicolumn{2}{|c|}{2 days } & \multicolumn{2}{|c|}{3 days } & \multicolumn{2}{|c|}{4 days } & \multicolumn{2}{|c|}{5 days } & \multicolumn{2}{|c|}{6 days } & \multicolumn{2}{|c|}{7 days } \\
\hline & $\mathrm{g}$ & $\%$ & $\mathrm{~g}$ & $\%$ & g & $\%$ & g & $\%$ & g & $\%$ & $\mathrm{~g}$ & $\%$ & g & $\%$ \\
\hline 1 & 506 & 100 & 491 & 97 & 477 & 94.3 & 465 & 91.9 & 451 & 89.1 & 437 & 86.4 & 425 & 84 \\
\hline 2 & 506 & 100 & 479 & 94,7 & 450 & 88.9 & 427 & 84.4 & 417 & 82.4 & 413 & 81.6 & 410 & 81 \\
\hline 3 & 516 & 100 & 457 & 88.6 & 421 & 81.6 & 417 & 80,8 & 415 & 80.4 & 415 & 80.4 & 415 & 80.4 \\
\hline \multirow{2}{*}{ No } & \multicolumn{2}{|c|}{8 days } & \multicolumn{2}{|c|}{9 days } & \multicolumn{2}{|c|}{10 days. } & \multicolumn{2}{|c|}{11 days. } & \multicolumn{2}{|c|}{12 days. } & \multicolumn{2}{|c|}{13 days. } & \multicolumn{2}{|c|}{14 days. } \\
\hline & $\mathrm{g}$ & $\%$ & g & $\%$ & $\mathrm{~g}$ & $\%$ & g & $\%$ & $\mathrm{~g}$ & $\%$ & g & $\%$ & g & $\%$ \\
\hline 1 & 419 & 82,8 & 413 & 81.6 & 408 & 80.6 & 406 & 80.2 & 405 & 80 & 404 & 79,8 & 404 & 79,8 \\
\hline 2 & 409 & 80,8 & 408 & 80.6 & 406 & 80.2 & 405 & 80 & 404 & 79,8 & 404 & 79,8 & 404 & 79,8 \\
\hline 3 & 415 & 80.4 & 415 & 80.4 & 415 & 80.4 & 415 & 80.4 & 415 & 80.4 & 415 & 80.4 & 415 & 80.4 \\
\hline
\end{tabular}

The analysis of moisture loss processes during drying is conveniently carried out on the basis of the normalized graphic of moisture content, plotted following the data in Table 1 (Fig. 2). Normalization was carried out taking into account the maximum moisture loss (the conventional value $\mathrm{W}=0 \%$ ). It should be remembered about the presence of capillary bound water, physically bound water in the form of adsorption layers and, finally, hydration water.

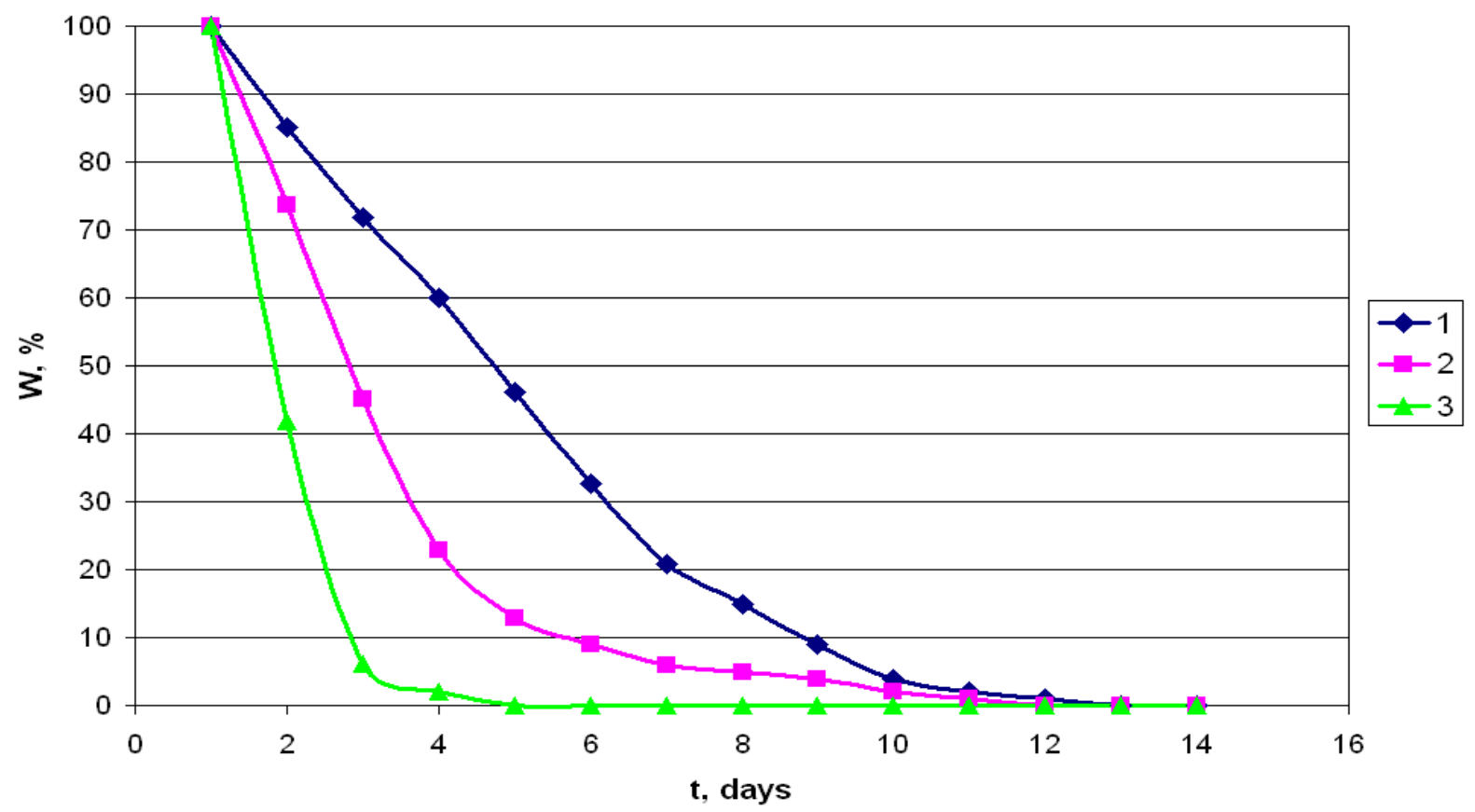

Fig. 2. Dependence graph of normalized moisture from sample drying time (1-3- number of samples)

The results presented in Table. 1 and Fig. 2, show that sample 2 dries faster than sample 1, in other words moisture transfer through the angle and rib areas of cubic samples occurs faster than through the surfaces of the faces. Qualitative ratios are also retained for the modes of constant drying rate. The fitted differential curve, plotting the dependence of the drying rate on time, shows it clearly (Fig. 3). 


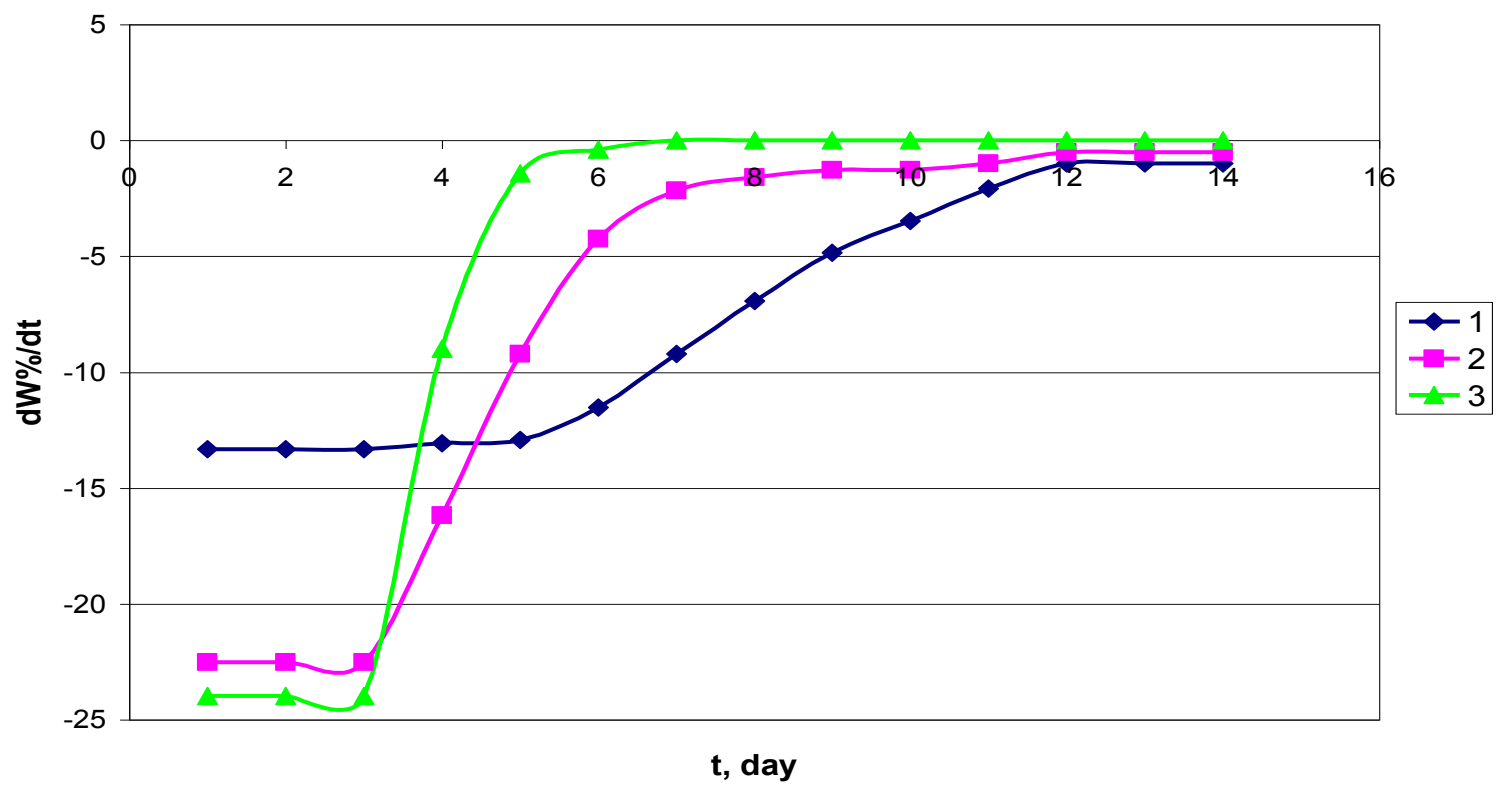

Fig. 3. Differential curves of drying processes (1-3 - number of samples)

For sample 1 the drying mode with constant speed is limited by 5 days. For sample 2 and 3 (without polymer coating) the intervals of linear drying are close (3.5 days). The interval of decrease in the moisture loss rate for the examined samples (from the end of the linear drying section to the saturation range) is also different. For sample 1, it is 7 days, for sample it is 2-3 days, for the control sample -1.5 days.

Theoretical concept of the material's drying processes and nature at the process at the different stages allows to highlight the following interpretation of obtained data. In the control sample, the constant drying rate corresponds to the evaporation process, accompanied by the simultaneous transfer of free water to the surface from the central areas of the sample along a capillary network of micropores (Fig. 4, a).

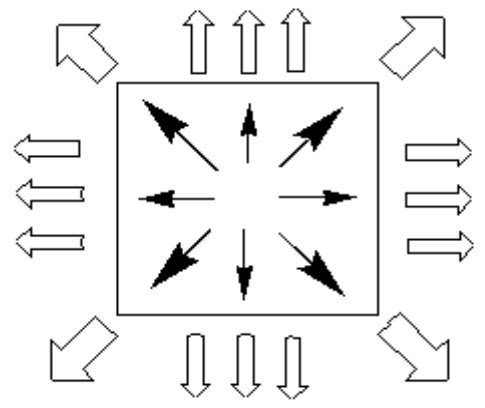

a)

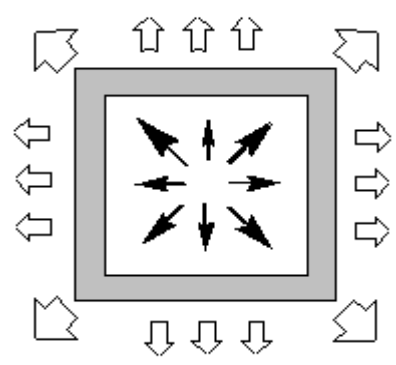

b)

Fig. 4. Diagram of the processes during the drying of the cubic sample No.3:

$\mathrm{a}$ - constant drying rate; $\mathrm{b}$ - underspeed drying condition. The area of low moisture content is highlighted with grey colour, capillary moisture transfer - the solid arrows, hollow - arrows show the intensity of evaporation

The underspeed condition corresponds to the formation of the area region of low moisture content on the sample periphery, near its surface (Fig. 4, b). The nature of this area and the time of the corresponding periods substantially depend on the material properties and, particularly, its porous structure.

Similar processes occur in samples 1 and 2, partially coated with a polymer film. In the case of constant drying speed mode capillary transfer is carried out both from central and neighboring isolated areas of the material. The moisture transfer here is partially limited and complicated by the 
boundary conditions set experimentally. It has a particularly strong effect on the durations of the corresponding periods for sample 1, with sealed rib and angle areas (Fig. 5).

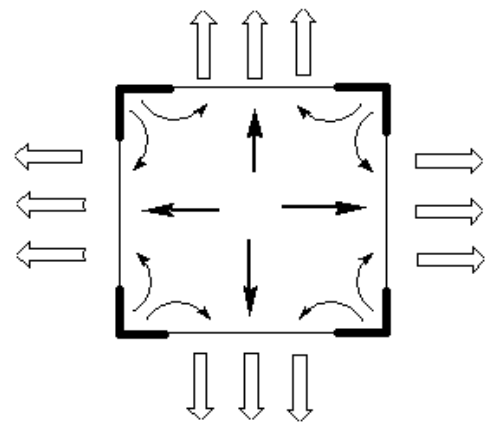

a)

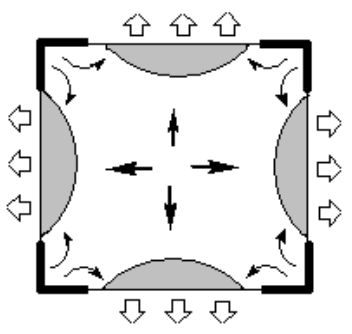

b)

Fig. 5. The nature of the processes occurring during the drying of sample 1:

$\mathrm{a}$ - constant drying speed mode; $\mathrm{b}$ - speed reduction stage. Shaded areas at the corners of the squares are an insulating coating. The area of low moisture content is highlighted with gray color, the solid arrows show capillary moisture transfer, and hollow ones show evaporation rate

The geometrical character of the areas of low moisture content seems to be more complex, associated with local flows of moisture transfer along the capillary network. The process nature of moisture transfer will be affected by the anisotropy of through-porosity, which often occurs in the composites during the period of structure formation.

In the case of sample 2, the intervals of constant drying rate increase in comparison with the control one are not so significant.

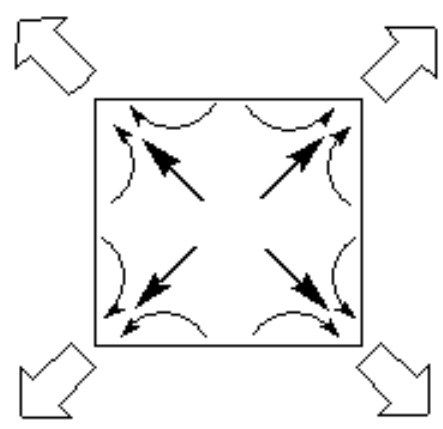

a)

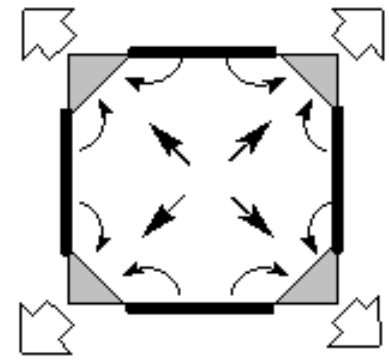

b)

Fig. 6. The processes occurring during the drying of sample 2:

$\mathrm{a}$ - constant drying mode; $\mathrm{b}$ - speed reduction stage. The dark areas at the corners of the squares are insulating coating. The area of low moisture content is highlighted with gray color, the solid arrows show capillary moisture transfer, and hollow ones show evaporation rate

This is explained by several reasons, primarily by the geometric characteristics of the free surface of the samples. In the case of sample 1, the evaporation occurs from the surface of the cube faces, in the case of sample 2, from the edges and angles, that means, if you summarize and take into account the real geometry of the sample, from the areas of higher curvature. The capillary leakage of the moisture to the corner parts also occurs faster (this factor is substantially determined by the characteristics of the material).

So, the geometric characteristics of the surface of model samples (particularly, its curvature), and, consequently, the shape of building structures significantly affect the processes of moisture transfer. This mechanism allows to choose under other equal conditions, the form of the structural elements, providing the maximum speed of moisture loss during drying (with the presence of rib and corner surface areas). 
Conclusions. The interrelated processes at moisture loss of the material during the drying process under different boundary conditions are examined in the research paper. The significant influence of the nature of the free surface, its curvature, the presence of rib and corner sections on the rate of moisture loss are found. The presence of these features leads to the increase of the rate of moisture transfer and moisture loss.

High quality maintenance of plaster compositions and other building materials is carried out by regulating of their structure formation at various scale levels . Most often, the optimum selection of composition and technological factors that have a significant impact on the macro-, meso- and microstructure. In recent decades, another nano-level has been involved in the optimization process of materials. Carrying out different-scale effects on the structure, leading to the formation of particleparticle packings of aggregates and new formations, reducing porosity and, influencing the mineral components of the material at the submolecular level, it is possible to improve significantly not only the strength, but also the moisture characteristics (moisture resistance) of the composites. It is necessary to examine the problem of product shape or design, optimizing the operational characteristics of the material and particularly moisture-resistant together with these directions of construction material engineering.

Choosing the composition of the material, by the impact on moisture flows structure during drying due to boundary conditions and forming of special elements of the outer surface (edges, angles), it is possible to provide a moisture mode, characterized by the least destruction effects formed in the material design. Such tasks may be the subject of further investigations in this direction.

\section{References}

[1] L.I. Dvorkin, O.L. Dvorkin, Stroitel'nyye mineral'nyye vyazhushchiye materialy. M.: InfraInzheneriya, 2011.

[2] A.B. Lykov, YU.A. Mikhaylov, Teoriya teplo- i massoperenosa. M.: Gosenergoizdat, 1963.

[3] J. Petkovic, H.P. Huinink, L. Pel, K. Kopinga, van Hees RPJ, "Salt transport in plaster/substrate layers", Materials and Structures, 40, pp. 475-490, 2007.

[4] P. Coussot, Scaling approach of the convective drying of a porous medium, Eur. Phys. J. B, 15, pp. 557-566, 2000.

[5] Van Brakel J, "Mass transfer in convective drying", Advances in drying, Hemisphere, Washington, Vol. 1, 1980.

[6] Van der Heijden GHA, L. Pel, HP. Huinink, K. Kopinga, "Moisture transport and dehydration in heated gypsum", an NMR study, Chem. Eng. Sci., 66, pp. 4241-4250, 2011.

[7] B. Vosten, B. Hersfeld, "The drying of crust-forming materials as exemplified by the drying of gypsum wallboard", Zement-Kalk-Gips, 5, pp. 213-222, 1976.

[8] P. Schultz, EU. Schlünder, "Influence of additives on crust formation during drying", Chem. Eng. Process, 28, pp. 133-142, 1990.

[9] S. Gupta, HP. Huinink, M. Prat, L. Pel, K. Kopinga, "Paradoxical drying of a fired-clay brick due to salt crystallization", Chem. Eng. Sci., 109, pp. 204-211, 2014.

[10] RM. Espinosa-Marzal, GW. Scherer, "Impact of in-pore salt crystallization on transport properties", Environ. Earth Sci., 69, pp. 2657-2669, 2013.

[11] V.I. Solomatov, V.N. Vyrovoy, V.S. Dorofeyev, A.V. Sirenko, Kompozitsionnyye stroitel'nyye smaterialy i konstruktsii ponizhennoy materialoyemkosti. Kiyev, Budivel'nyk, 1991.

[12] V.G. Sukhanov, V.N. Vyrovoy, O.A. Korobko, Struktura materiala v strukture konstruktsii. Odessa, Poligraf, 2016. 


\section{ВЛИЯНИЕ ГЕОМЕТРИЧЕСКИХ ХАРАКТЕРИСТИК ИЗДЕЛИЯ НА КИНЕТИКУ ВЛАГОПОТЕРИ}

И.В. Довгань, Д.Х.н., професcop, ORCID: 0000-0002-6195-4890

А.В. Колесников, к.т.н., доцент, ORCID: 0000-0001-8737-0933

C.В. Семенова, к.т.н., доцент, svetas@inbox.ru, ORCID: 0000-0002-5309-5854

Г.А. Кириленко, ORCID: 0000-0001-9377-1530

Е.А. Маковецкая, ORCID: 0000-0002-3135-4333

Одесская государственная академия строительства и архитектурь

Аннотация. В статье рассматривается влияние геометрических характеристик поверхности строительных изделий на процессы влагопотери при их высушивании. Высушивание строительного изделия рассматривается как активный физико-химический процесс, чувствительный к геометрическим свойствам потоков влагопереноса. Характеристика этих потоков определяется, в частности, граничными условиями, налагаемыми на увлажненный композит формой изготовленного из него образца или конструкции. Поскольку высушивание строительного изделия представляет собой сложный процесс, обусловленный взаимосвязанными изменениями локального влагосодержания, деформации композита и изменения его физико-химических характеристик, экспериментально исследовано суммарное влияние граничных условий на скорость влагопотери образцов. Рассматривается скорость потери массы за счет высушивания в стандартных условиях серии кубических образцов, частично покрытых полимерной пленкой таким образом, что свободными для испарения влаги остаются одинаковые по площади участки граней и части поверхности, содержащие ребра и вершины. Кинетика влагопотери исследовалась с помощью построения и анализа нормированного графика влагосодержания и соответствующих дифференциальных графических зависимостей. На основе дифференциальных графиков выделялись интервалы постоянной скорости влагопотери и снижения скорости сушки. Показано, что интервал постоянной скорости сушки в случае образца с изолированными ребрами и вершинами существенно больше по сравнению с образцом с изолированными гранями. Интервал падения скорости сушки наименьший у контрольного образца и наибольший у образца с изолированными ребрами и вершинами. Приведена концептуальная интерпретация полученных результатов: скорость влагопотери, как в случае режима постоянной скорости сушки, так и в условиях падения скорости сушки, выше у образцов со свободными ребрами и углами, чем у образцов со свободными гранями, благодаря влиянию геометрии поверхности образца (ее кривизны) на процессы испарения и перемещения влаги по капиллярной сети материала. Таким образом, продемонстрировано существенное влияние геометрии поверхности образцов, ее кривизны, наличия ребер и углов, на характер влагопотерь. Рассматривается возможность создания строительных конструкций специальной геометрии (наличие ребер и кривизны) для оптимизации процессов высушивания и минимизации эффектов влажностного разрушения материала.

Ключевые слова: скорость влагопотери, влагоперенос, высушивание, геометрия поверхности.

\section{ВПЛИВ ГЕОМЕТРИЧНИХ ХАРАКТЕРИСТИК ВИРОБІВ НА КІНЕТИКУ ВОЛОГОВТРАТИ}

I.B. Довгань, д.Х.н., професор, ORCID: 0000-0002-6195-4890

А.В. Колесніков, к.т.н., доцент, ORCID: 0000-0001-8737-0933 
С.В. Семенова, к.т.н., доцент, svetas@inbox.ru, ORCID: 0000-0002-5309-5854

Г.А. Кириленко, ORCID: 0000-0001-9377-1530

Е.А. Маковецька, ORCID: 0000-0002-3135-4333

Одеська державна академія будівництва і архітектури

Анотація. У статті розглядається вплив геометричних характеристик поверхні будівельних виробів на процеси вологовтрати при їх висушуванні. Висушування будівельного виробу розглядається як активний фізико-хімічний процес, чутливий до геометричних властивостей потоків вологопереносу. Характеристика цих потоків визначається, зокрема, граничними умовами, що накладаються на зволожений композит формою виготовленого з нього зразка або конструкції. Оскільки висушування будівельного виробу являє собою складний процес, обумовлений взаємопов'язаними змінами локального вмісту вологи, деформації композиту i зміни його фізико-хімічних характеристик, експериментально досліджено сумарний вплив граничних умов на швидкість вологовтрати зразків. Розглядається швидкість втрати маси за рахунок висушування в стандартних умовах серії кубічних зразків, частково покритих полімерною плівкою таким чином, що вільними для випаровування вологи залишаються однакові за площею ділянки граней і частини поверхні, що містить ребра і вершини. Кінетика вологовтрати досліджувалася за допомогою побудови i аналізу нормованого графіка вологовмісту і відповідних диференціальних графічних залежностей. На основі диференціальних графіків виділялися інтервали постійної швидкості вологовтрати і зниження швидкості сушіння. Показано, що інтервал постійної швидкості сушіння у зразка 3 ізольованими ребрами і вершинами істотно більше в порівнянні з зразком з ізольованими гранями. Інтервал падіння швидкості сушки найменший у контрольного зразка і найбільший у зразка з ізольованими ребрами і вершинами. Наведено концептуальну інтерпретацію отриманих результатів: швидкість вологовтрати у випадку режиму постійної швидкості сушіння, так і в умовах падіння швидкості сушки, вища у зразків з вільними ребрами і вершинами, ніж у зразків з вільними гранями, завдяки впливу геометрії поверхні зразка (ії кривизни) на процеси випаровування і переміщення вологи по капілярній мережі матеріалу. Таким чином, продемонстровано суттєвий вплив геометрії поверхні зразків, її кривизни, наявності ребер і кутів, на характер вологовтрат. Розглядається можливість створення будівельних конструкцій спеціальної геометрії (наявність ребер i кривизни) для оптимізації процесів висушування і мінімізації ефектів вологісного руйнування матеріалу.

Ключові слова: швидкість вологовтрати, вологоперенос, висушування, геометрія поверхні.

Стаття надійшла 13.03.2018 